\section{Physiological and antioxidant changes in sunflower seeds under water restriction}

\author{
Thais de Castro Morais ${ }^{1}$ (D) Daniel Teixeira Pinheiro ${ }^{1^{*}}$ (D) , Paola Andrea \\ Hormaza Martinez $^{1}$ (D) , Fernando Luiz Finger $^{1}(\mathbb{D})$, Denise Cunha Fernandes \\ dos Santos Dias ${ }^{1}$
}

\begin{abstract}
Seed vigor may be determinant for field performance, especially under water restriction conditions. Sunflower is a crop subject to these conditions in the field and, therefore, the aim of this study was to evaluate the physiological and antioxidant changes in sunflower seeds under water restriction. Two lots of sunflower seeds (cv. Hélio 253) with different vigor levels were used. After initial characterization, seeds were placed to germinate under water potentials of $0.0,-0.2,-0.4,-0.6$ and $-0.8 \mathrm{MPa}$ and evaluated by tests of germination, first germination count, shoot length and primary root length. The activities of the antioxidant enzymes SOD, CAT, POX and APX were also evaluated at 0, 2, 4 and 6 days after sowing. Water restriction led to a decrease in germination and slower seedling growth, regardless of seed vigor level. SOD activity was similar in the two lots, with reduction in activity four days after sowing. CAT activity was affected differently during germination in the two lots, and it was generally higher in the most vigorous lot. In higher vigor seeds, there was lower POX activity in water restriction treatments compared to the control. In general, seeds of lower vigor have lower capacity for activation of antioxidant enzymes, especially peroxidases.
\end{abstract}

Index terms: enzyme analysis, water deficit, germination, Helianthus annuus L., vigor.

\section{Alterações fisiológicas e antioxidativas em sementes de girassol submetidas à restrição hídrica}

RESUMO: O vigor das sementes pode ser determinante para o seu desempenho em campo, especialmente sob condições de restrição hídrica. $O$ girassol é uma cultura sujeita as essas condições no campo, e assim, o objetivo do trabalho foi avaliar as alterações fisiológicas e antioxidativas em sementes de girassol submetidas à restrição hídrica. Foram utilizados dois lotes da cv. Hélio 253 diferindo quanto ao vigor. Após a caracterização inicial, as sementes foram colocadas para germinar sob os potenciais de 0,$0 ;-0,2 ;-0,4 ;-0,6$ e $-0,8 \mathrm{MPa}$ e avaliadas quanto a germinação, primeira contagem e comprimento de parte aérea e raiz primária. Foram avaliadas também as atividades das enzimas antioxidativas SOD, CAT, POX e APX aos 0, 2, 4 e 6 dias após a semeadura. A restrição hídrica provocou decréscimo na germinação e menor crescimento das plântulas independentemente do nível de vigor das sementes. A atividade da SOD foi semelhante para os dois lotes, com redução aos quatro dias após a semeadura. A atividade da CAT foi afetada de modo diferente ao longo da germinação dos dois lotes sendo, em geral, mais alta no lote de maior vigor. Nas sementes de maior vigor, houve menor atividade da POX nos tratamentos de restrição hídrica em relação ao controle. Em geral, sementes de menor vigor possuem menor capacidade de ativação de enzimas antioxidativas, principalmente as peroxidases.

Termos para indexação: análise enzimática, déficit hídrico, germinação, Helianthus annuus L., vigor.
Journal of Seed Science, v.42, e202042008, 2020

http://dx.doi.org/10.1590/2317$1545 v 42225777$

\section{*Corresponding author E-mail: pinheiroagroufv@gmail.com}

Received: 7/9/2019. Accepted: 10/22/2019.

${ }^{1}$ Universidade Federal de Viçosa (UFV), Departamento de Agronomia, 36570-900 - Viçosa, MG, Brasil. 


\section{INTRODUCTION}

The expressive increase in planted area of sunflower (Helianthus annuus L.) has led to an increase in the demand for high quality seeds. Sunflower is grown in most Brazilian states and is concentrated especially in the Cerrado region (Brazilian tropical savanna) between the soybean and maize crop seasons. It is of fundamental importance in rotation systems (CONAB, 2017). The crop is subject to variations in edaphic and climatic conditions, mainly in regard to soil water availability in the seedling emergence phase (Backes et al., 2008).

Water restriction in the soil at the time of sowing reduces the emergence and development of seedlings due to interference in the water uptake and cell elongation processes (Finch-Savage and Bassel, 2016; Marcos-Filho, 2015). Under water stress conditions, field emergence and initial seedling development depend on the level of seed vigor. Albuquerque and Carvalho (2003) found that the effect of seed vigor in sunflower on reduction of field emergence is associated with stress conditions at the time of sowing. These authors found that under water restriction at $-1.1 \mathrm{MPa}$, obtained by moisture control in the soil, there was reduction in seedling emergence even for higher vigor seed lots.

In a study carried out with two sunflower cultivars under water stress, Carneiro et al. (2011) observed a reduction in germination, length, and dry matter of seedlings, above all at the water potential of $-0.8 \mathrm{MPa}$ with the use of polyethylene glycol (PEG 6000). Similar results were observed by Luan et al. (2014), using the osmotic agents PEG 6000 and sodium chloride $(\mathrm{NaCl})$.

Water restriction during the germination process can lead to oxidative stress in seeds and increase the production of reactive oxygen species (ROSs), such as the superoxide radical $\left(\mathrm{O}_{2}^{-}\right)$, the hydroxyl radical $\left(\mathrm{OH}^{-}\right)$, hydrogen peroxide $\left(\mathrm{H}_{2} \mathrm{O}_{2}\right)$ and singlet oxygen $\left({ }^{1} \mathrm{O}_{2}\right)$ (Jaleel et al., 2007; Mouradi et al., 2016; Nguyen et al., 2019). The intensity of cell damage is determined by the capacity of seeds to eliminate these free radicals through defense systems, including the action of antioxidant enzymes, which promote control of the intracellular concentration of ROSs (Kapoor et al., 2015). The inner content of these compounds and the activation of the antioxidant defense system are associated with successful germination, especially in situations of abiotic stresses (Chen and Arora, 2013; Jisha et al., 2013; Savvides et al., 2016).

Among the main antioxidant enzymes, superoxide dismutase (SOD), catalase (CAT), peroxidase (POX), and ascorbate peroxidase (APX) are constantly regulated in the process of neutralization of excessive ROSs at the cell level (Bailly, 2004; Del Río et al., 2018; Groß et al., 2013; Kibinza et al., 2011). However, this regulation may be inefficient if the stress is more accentuated, with an increase in free radical production. In sunflower seeds, antioxidant enzyme activity and seed physiological potential were not affected when under water stress and salt stress up to the water potential of -0.4 MPa, but under the potential of -0.8 MPa, antioxidant capacity during germination was reduced, affecting seedling growth (Carneiro et al., 2011).

Low vigor seeds are less efficient in neutralizing ROSs and, thus, oxidative stress increases ROS production and, consequently, reduces germination (Bailly, 2004). In oil seeds such as sunflower, the effects of oxidative stress are mainly related to peroxidation of lipids and oxidation of proteins and nucleic acids (Bailly et al., 2008; Xin et al., 2014; Yin et al., 2015). In general, studies on water stress in sunflower seeds do not consider the level of seed vigor and mainly evaluate aspects related to germination, emergence and seedling growth (Albuquerque and Carvalho, 2003; Carneiro et al., 2011; Luan et al., 2014). Therefore, the aim of this study was to evaluate the physiological potential and changes in the antioxidant enzyme system of sunflower seeds, with different vigor levels, when under water restriction.

\section{MATERIAL AND METHODS}

This study was conducted in the Seed Laboratory of the Plant Science Department of the Universidade Federal de Viçosa, Viçosa, MG, Brazil. Two seed lots of sunflower of the cultivar Hélio 253 were used, collected in the 2014 crop season and supplied by the HELIAGRO company. First, the seeds from each lot were evaluated in regard to physiological quality by the following tests: 
Germination: This was conducted with eight replications of 25 seeds, following the method described in the Rules for Seed Testing (Brasil, 2009). The seeds were sown in paper moistened with water in the amount of 2.5 times the weight of the dry paper. Rolls were formed and they were kept in a seed germinator at $25{ }^{\circ} \mathrm{C}$, with an eight-hour photoperiod. The number of normal seedlings were counted ten days after sowing, and results were expressed in percentage (Brasil, 2009).

First germination count: This was conducted together with the germination test, calculating the percentage of normal seedlings obtained on the fourth day after sowing (Brasil, 2009).

Shoot length and root length: Four replications of ten seeds were sown at an equal distance on a line drawn on the upper third of the rolls of paper towel moistened to 2.5 times the weight of the dry substrate and kept at 25 o $\mathrm{C}$ with an eight-hour photoperiod (Nakagawa et al., 1999). On the tenth day after sowing, shoot length and root length of the seedlings were measured through use of a ruler, and the results were expressed in $\mathrm{cm}_{\text {.seedling }}^{-1}$.

Seedling emergence: This was carried out in a greenhouse in trays containing a substrate of soil and sand in the proportion of 2:1. Four replications of fifty seeds were sown at a depth of $1 \mathrm{~cm}$, and daily counts were made until stabilization of the number of seedlings to calculate the percentage of seedling emergence and the emergence speed index (ESI) (Maguire, 1962).

Accelerated aging: This was carried out with 250 seeds, distributed over a screen within a "Gerbox" plastic box containing $40 \mathrm{~mL}$ of distilled water at the bottom. The boxes were closed with a lid, enclosed in plastic bags, and kept in a BOD incubator at $41{ }^{\circ} \mathrm{C}$ for 48 hours. After that period, the seeds were placed to germinate as described for the germination test. The percentage of normal seedlings was evaluated at four days after sowing.

Electrical conductivity: two hundred seeds, subdivided into four replications of fifty seeds from each lot and previously weighed, were placed in plastic cups containing $75 \mathrm{~mL}$ of distilled water and kept in a seed germinator at the temperature of $25^{\circ} \mathrm{C}$ for 24 hours. After that period, the electrical conductivity of the solution was measured with a conductivity meter, and results were expressed in $\mu \mathrm{S} \mathrm{cm}^{-1} \cdot \mathrm{g}^{-1}$.

Seeds from each lot were subjected to water restriction. For that purpose, they were placed to germinate as described above for the germination test using paper moistened with PEG 6000 solutions at the following potentials: 0.0 (control), $-0.2,-0.4,-0.6$ and $-0.8 \mathrm{MPa}$, obtained according to Villela et al. (1991). Germination was evaluated at four and ten days after sowing, and results were expressed in percentage of normal seedlings (Brasil, 2009). Root length and shoot length were measured as described for characterization of the lots.

For evaluation of antioxidant enzyme activity, seeds were used at 0 days (twelve hours of imbibition in paper towel moistened with water; control) and after 2, 4 and 6 days of germination for all treatments under water restriction. To obtain the extracts used in determinations of the activity of the enzymes superoxide dismutase (SOD), catalase (CAT), peroxidase (POX) and ascorbate peroxidase (APX), the plant material was frozen in liquid nitrogen and kept at $-80^{\circ} \mathrm{C}$. After that, around $0.3 \mathrm{~g}$ of plant matter was macerated and $2 \mathrm{~mL}$ of extraction medium, potassium phosphate buffer $(0.1 \mathrm{M}, \mathrm{pH}$ 6.8) was added, containing $0.1 \mathrm{mM}$ ethylenediamine tetraacetic acid (EDTA), $1 \mathrm{mM}$ phenylmethylsulfonyl fluoride (PMSF) and $1 \%$ polyvinylpolypyrrolidone (PVPP) (w/v) (Peixoto et al., 1999). After that, the material was homogenized and then centrifuged twice at $15,000 \mathrm{xg}$ for fifteen minutes at $4{ }^{\circ} \mathrm{C}$ to remove the oil layer from the supernatant.

Superoxide dismutase (SOD): The method proposed by Del Longo et al. (1993) was used, adjusted for sunflower seeds, through addition of $30 \mu \mathrm{L}$ of crude enzyme extract to $2.97 \mathrm{~mL}$ of the reaction medium sodium phosphate buffer (50 mM, pH 7.8), containing $13 \mathrm{mM}$ methionine, $75 \mu \mathrm{M}$ nitroblue tetrazolium (NBT), $0.1 \mathrm{mM}$ EDTA and $2 \mu \mathrm{M}$ riboflavin. The reaction was conducted at $25^{\circ} \mathrm{C}$ for five minutes in a reaction chamber lighted with $15 \mathrm{~W}$ fluorescent bulbs. The blank was obtained under the same conditions, however, in the absence of light. Thus, the photoreduction of the NBT was determined by measuring absorbance at $560 \mathrm{~nm}$ (Giannopolitis and Ries, 1977). A unit of SOD was defined as the amount of enzyme able to inhibit 50\% of the photoreduction of the NBT (Beauchamp and Fridovich, 1971).

Catalase (CAT): This was determined according to the protocol proposed by Havir and McHale (1987) through addition of $30 \mu \mathrm{L}$ of the crude enzyme extract in $2.97 \mathrm{~mL}$ of the reaction medium potassium phosphate buffer ( $50 \mathrm{mM}$, 
$\mathrm{pH} 7.0$ and $12.5 \mathrm{mM} \mathrm{H}_{2} \mathrm{O}_{2}$ ). Enzyme activity was obtained based on reading in a spectrophotometer at the wavelength of $240 \mathrm{~nm}$ during the first minute of the reaction at $25^{\circ} \mathrm{C}$, and then calculated using the molar extinction coefficient of $36 \mathrm{M}^{-1} \cdot \mathrm{cm}^{-1}$ (Anderson et al., 1995). The results were expressed in $\mu \mathrm{mol} . \mathrm{min}^{-1} \cdot \mathrm{mg}^{-1}$ of protein.

Peroxidase (POX): This was determined by the addition of $50 \mu \mathrm{L}$ of the crude enzyme extract to $2.95 \mathrm{~mL}$ of the reaction medium potassium phosphate buffer $(25 \mathrm{mM}, \mathrm{pH} 6.8), 20 \mathrm{mM}$ pyrogallol and 20 mM hydrogen peroxide. During the first minute of reaction, the increase in absorbance was observed at the wavelength of $420 \mathrm{~nm}$ at $25^{\circ} \mathrm{C}$. Enzyme activity was calculated using the molar extinction coefficient of $2.47 \mathrm{mM} . \mathrm{L}^{-1} . \mathrm{cm}^{-1}$ (Chance and Maehly, 1955) and expressed in $\mu \mathrm{mol} . \mathrm{min}^{1} \mathrm{mg}^{-1}$ of protein.

Ascorbate peroxidase (APX): This was determined through addition of $50 \mu \mathrm{L}$ of the crude enzyme extract in 2.95 $\mathrm{mL}$ of the reaction medium potassium phosphate buffer $(50 \mathrm{mM}, \mathrm{pH} 7.8)$, containing $0.25 \mathrm{mM}$ ascorbic acid, $0.1 \mathrm{mM}$ EDTA and $0.3 \mathrm{mM} \mathrm{H}_{2} \mathrm{O}_{2}$. The decrease in absorbance at $290 \mathrm{~nm}$ was observed during the first minute at $25^{\circ} \mathrm{C}$. Enzyme activity was calculated using the molar extinction coefficient $2.8 \mathrm{mM}^{-1} \cdot \mathrm{cm}^{-1}$ (Nakano and Asada, 1981), and the result was expressed in $\mu \mathrm{mol}$. $\mathrm{min}^{-1}$. $\mathrm{mg}^{-1}$ of protein.

Protein content: This was determined by the method of Bradford (1976), using BSA as a standard. The quantity of $100 \mu \mathrm{L}$ of the enzyme extract was used, adding $1 \mathrm{~mL}$ of the Bradford reagent, followed by shaking. After twenty minutes, absorbance of the sample was read in a spectrophotometer at $595 \mathrm{~nm}$. The data were used for calculations of antioxidant enzyme activity.

Experimental design and statistical analysis: The experiment was set up in a completely randomized design with four replications. The data obtained in the tests of germination, first germination count, plant length and plant dry matter were analyzed in a 2 (lots) $\times 5$ (osmotic potentials) factorial arrangement, and then by regression analysis. The data on enzyme activity, lipid peroxidation (MDA) and protein content were analyzed in a 2 (lots) $\times 5$ (osmotic potentials) $\times 4$ (days after sowing - DAS) factorial arrangement and were represented by the mean value, with the respective standard deviation.

\section{RESULTS AND DISCUSSION}

The two sunflower seed lots had similar germination percentages. Nevertheless, they differed in regard to vigor by the tests of first germination count, accelerated aging, seedling emergence, emergence speed index and electrical conductivity, with greater vigor for the seeds of lot 1 (Table 1 ).

There was reduction in germination and in first germination count in both seed lots with the decrease in osmotic potential (Figure 1). The increase in osmotic concentration of the PEG 6000 solution reduces water absorption by

Table 1. Characterization of the physiological potential of seeds of lots 1 and 2 of sunflower, cultivar Hélio 253.

\begin{tabular}{|c|c|c|c|c|c|}
\hline Lot & $\begin{array}{c}\text { Germination } \\
(\%)\end{array}$ & $\begin{array}{l}\text { First germination } \\
\text { count }(\%)\end{array}$ & $\begin{array}{c}\text { Accelerated aging } \\
(\%)\end{array}$ & $\begin{array}{c}\mathrm{SL} \\
\left(\mathrm{cm} \cdot \text { seedling }^{-1}\right)\end{array}$ & $\begin{array}{c}\mathrm{RL} \\
\left(\mathrm{cm}^{\text {seedling }}{ }^{-1}\right)\end{array}$ \\
\hline 1 & $95 \mathrm{~A}$ & $91 \mathrm{~A}$ & $92 \mathrm{~A}$ & $11.9 \mathrm{~A}$ & $13.7 \mathrm{~A}$ \\
\hline 2 & $91 \mathrm{~A}$ & $80 \mathrm{~B}$ & $73 \mathrm{~B}$ & $10.1 \mathrm{~A}$ & $12.4 \mathrm{~A}$ \\
\hline CV (\%) & 3.0 & 5.5 & 11.3 & 18.0 & 24.3 \\
\hline Lot & $\begin{array}{c}\text { SDM } \\
\text { (mg.seedling }{ }^{-1} \text { ) }\end{array}$ & $\begin{array}{c}\text { RDM } \\
\left.\text { (mg.seedling }{ }^{-1}\right)\end{array}$ & $\begin{array}{l}\text { Emergence } \\
(\%)\end{array}$ & ESI & $\begin{array}{c}\text { Electrical } \\
\text { conductivity } \\
\left(\mu \mathrm{S} . \mathrm{cm}^{-1} \cdot \mathrm{g}^{-1}\right)\end{array}$ \\
\hline 1 & $45.0 \mathrm{~A}$ & $15.9 \mathrm{~A}$ & $100 \mathrm{~A}$ & $11.1 \mathrm{~A}$ & $65.2 \mathrm{~A}$ \\
\hline 2 & $44.8 \mathrm{~A}$ & $12.4 \mathrm{~A}$ & $86 \mathrm{~B}$ & $8.9 \mathrm{~B}$ & 75.7 B \\
\hline CV (\%) & 17.7 & 17.8 & 4.5 & 9.4 & 3.4 \\
\hline
\end{tabular}

$\mathrm{SL}$ = shoot length; $\mathrm{RL}$ = root length; $\mathrm{SDM}=$ shoot dry matter; $\mathrm{RDM}=$ root dry matter; $\mathrm{ESI}$ = emergence speed index. Mean values followed by the same letter in the row do not differ from each other by the $F$ test $(p<0.05)$. 
seeds, causing reduction in germination percentage (Lewandrowski et al., 2017). Generally, the germination percentage decreases along with the decrease in water potential, but for each species, there is a potential at which there is no germination (Ávila et al., 2007).

Results of the germination test showed that the two seed lots had linear reduction under water restriction. However, lot 1 (greater vigor) had higher germination than lot 2 (lower vigor), regardless of the potential tested (Figure 1A). Considering first germination count (Figure 1B), the most drastic water restrictions (-0.6 and -0.8 $\mathrm{MPa}$ ) had a similar effect for the two seed lots tested, with a percentage of normal seedlings near $0 \%$ (Figure 1B). In a study carried out with sunflower genotypes, González-Belo et al. (2014) observed that reductions in germination at the potentials -0.3 , $-0.6,-0.9$ and $-1.2 \mathrm{MPa}$ and different temperatures were correlated with linoleic acid contents in the seeds.

According to Barros and Rossetto (2009), reduction in sunflower seed germination occurs beginning at the water potential of $-0.3 \mathrm{MPa}$, and total inhibition of germination occurs at $-0.9 \mathrm{MPa}$. In the present study, the germination of lot 2 seeds reached levels near 0 at the potential of $-0.8 \mathrm{MPa}$ and of approximately $20 \%$ in lot 1 seeds (greater vigor) (Figure 1). It has already been observed that water stress in sunflower seeds brings about irregular germination and uneven establishment of seedlings (Albuquerque and Carvalho, 2003), and it reduces germination speed, as was observed in the first germination count test (Figure 1B).

Water restriction affected the initial development of the sunflower seedlings, with reduction in shoot length and root length as water restriction increased in the two seed lots (Figure 2). In general, water restriction affects germination and seedling development due to lower digestion and distribution of assimilates, and it limits diverse metabolic processes involved in the formation of new plant tissues and cell elongation (Bewley et al., 2013; FinchSavage and Bassel, 2016).

Similar results were obtained by Carneiro et al. (2011), where the shoot length of sunflower seedlings declined in a linear manner as the PEG 6000 concentration increased, with the lowest values at the potential of $-0.8 \mathrm{MPa}$. These authors reported that the root length at the potentials of -0.2 and $0.4 \mathrm{MPa}$ was greater than the control, decreasing from this water potential on, which was also observed in the present study (Figure 2B). These results can be explained by the adaptation mechanisms of the seedlings when they were under water stress, such as directing photoassimilates to greater root growth in an attempt to increase water uptake.

Another possible effect on reduction of sunflower seedling growth under water restriction is lower chlorophyll production, as observed by Singh et al. (2015) and Manivannan et al. (2015). Such reductions were also observed by
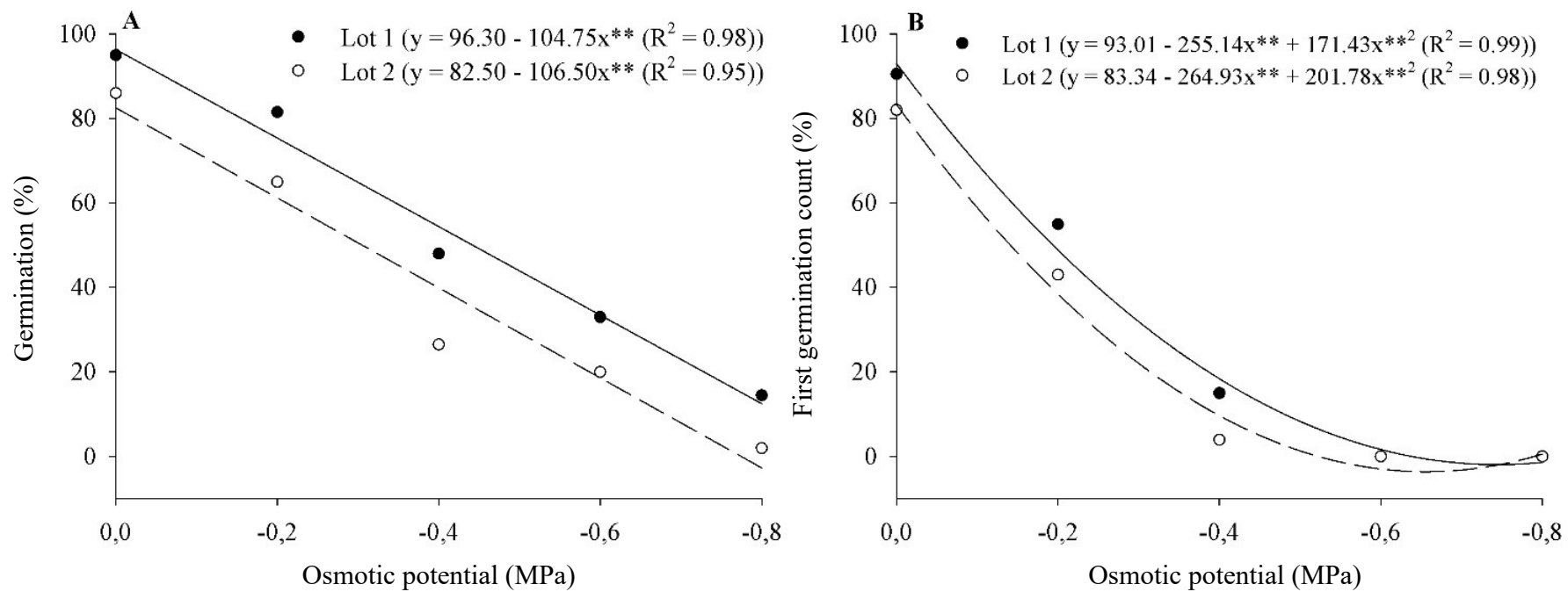

**: significant at $5 \%$ by the T-test.

Figure 1. Germination (A) and first germination count (B) of seeds from two sunflower seed lots, cultivar Hélio 253, under water restriction in PEG 6000 solutions. 
Farjzadeh et al. (2017) in different sunflower lines under water stress, and they associated these results to damage to the chloroplasts, caused by ROSs. In addition, the biosynthesis of chlorophyll precursors may be compromised under osmotic stress (Moharramnejad et al., 2015). Thus, reduction in osmotic potential led to a reduction in the germination percentage of the lots, regardless of seed vigor (Figure 1), associated with lower seedling growth, with reduction in shoot and root length (Figure 2).

In general, SOD activity was similar for the two seed lots tested, observing little change up to 4 days after sowing. In lot 1 (greater vigor), a slight reduction in activity was observed after four days for the potentials -0.2 and -0.8 MPa (Figure 3A). In lot 2 (lower vigor), this reduction was observed at all the osmotic potentials (Figure 3B). SOD constitutes a group of metalloenzymes that catalyze the dismutation or disproportionation of superoxide radicals $\left(\mathrm{O}_{2}{ }^{-}\right)$ into molecular oxygen $\left(\mathrm{O}_{2}\right)$ and hydrogen peroxide $\left(\mathrm{H}_{2} \mathrm{O}_{2}\right)$ and act in the first line of antioxidant defense (Del Río et al., 2018; Wang et al., 2016). Consequently, the increase in SOD activity is known to confer tolerance to oxidative stress caused by adverse environmental conditions (Jaleel et al., 2007). In a different way than observed in the present study, Fernández-Ocaña et al. (2011) observed a significant increase in SOD activity in sunflower seedlings under stress from low temperatures, even without apparent oxidative stress. These authors associate these observations to a genetic expression that activates this enzyme to prevent potential oxidative stress.

In lot 2 (lower vigor), the increase in SOD activity regardless of the potential, in relation to the control, was not observed, and was greatest at the potential of -0.8 MPa in all the times analyzed (Figure 3B). According to Bailly (2004), low vigor seeds have lower efficiency in elimination of ROSs, generating oxidative stress. In this lot, reduction in SOD activity for all the potentials tested from the fourth day on confirms the lower capacity of activation of this enzyme in lower vigor seeds (Figure 3B).

CAT is present in glyoxysomes and peroxisomes and, together with the peroxidases, it is responsible for conversion of $\mathrm{H}_{2} \mathrm{O}_{2}$ into $\mathrm{O}_{2}$ (Kibinza et al., 2011; Willekens et al., 1995). The activity of this enzyme was affected differently over the germination period in lots 1 and 2, and was generally higher in lot 1 (Figures $4 A$ and $B$ ).

There was variation in CAT activity over the germination period in the two lots tested. In lot 1 (greater vigor), an increase was observed at the potential of $-0.6 \mathrm{MPa}$ up to four days, decreasing at six days. At the potentials of -0.2 and $-0.4 \mathrm{MPa}$, the response was different, with reduction in activity from 0 to four days and increase at six days. Comparing the different potentials, at six days, differences among the potentials $0,-0.2$ and $-0.8 \mathrm{MPa}$ were not observed, and they were significantly higher at the potentials -0.4 and $-0.6 \mathrm{MPa}$ (Figure $4 \mathrm{~A}$ ). In lot 2 (lower vigor), in general, a reduction was observed in activity
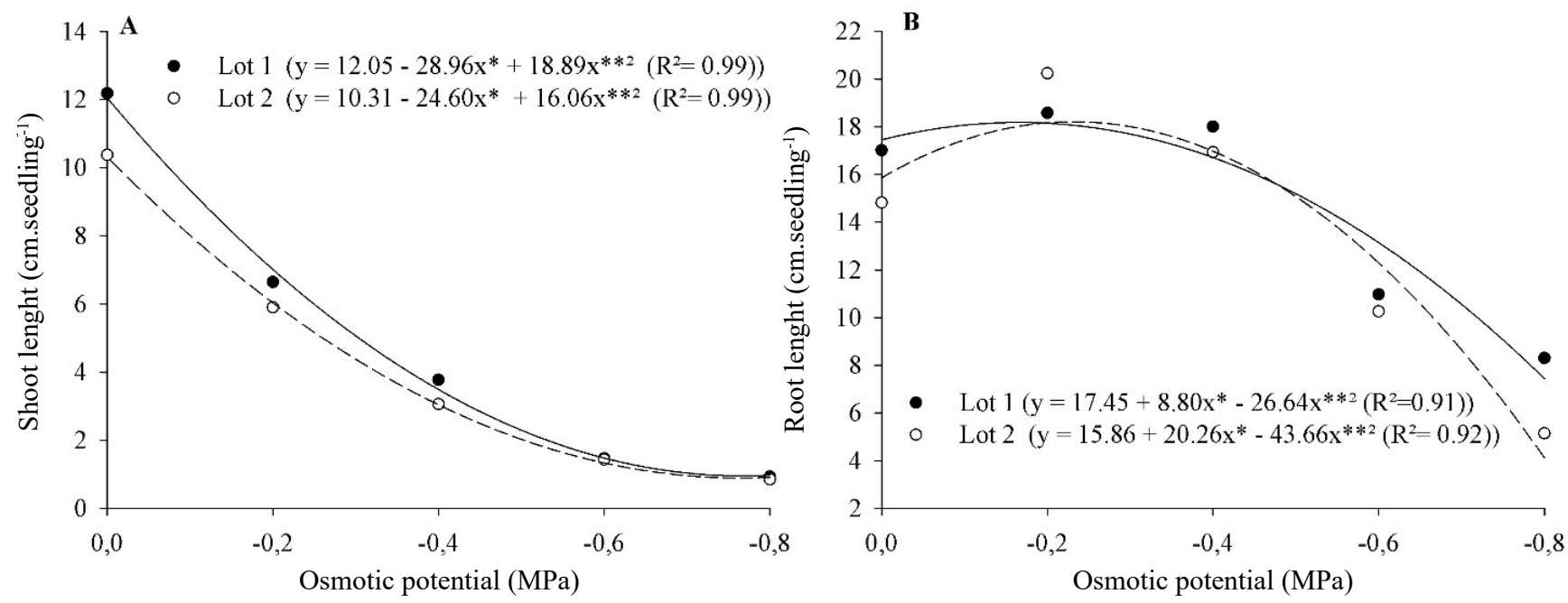

$$
*, * * \text { : significant at } 1 \% \text { and } 5 \% \text { by the T-test, respectively. }
$$

Figure 2. Shoot length (A) and root length (B) of sunflower seedlings from lots 1 and 2, cultivar Hélio 253, under water restriction in PEG 6000 solutions. 
up to two days, followed by an increase on the fourth day, and once more a decrease at six days (Figure 4B).

Reduction in CAT activity with the decrease in osmotic potential coincide with reduction in vigor observed by the tests of first germination count and shoot and root length (Figures 1 and 2). Carneiro et al. (2011) evaluated sunflower seedlings and found reduction in CAT activity at the water potential of $-0.8 \mathrm{MPa}$, also induced by PEG 6000 . In contrast, Naderi et al. (2014) observed an increase in CAT activity in wheat seedlings under the potentials of -0.4 and $-0.8 \mathrm{MPa}$ for five days.

Just like CAT, POX oxidizes organic substrates, with $\mathrm{H}_{2} \mathrm{O}_{2}$ as the electron receptor molecule, resulting in release of $\mathrm{H}_{2} \mathrm{O}$ and $\mathrm{O}_{2}$ (Mittler, 2002). POX activity was lower in the treatments with water stress in relation to the control (0 MPa) for the two lots evaluated, and it was more evident in lot 1 (higher vigor) (Figure 5). For the two lots, the potentials of

Lot 1

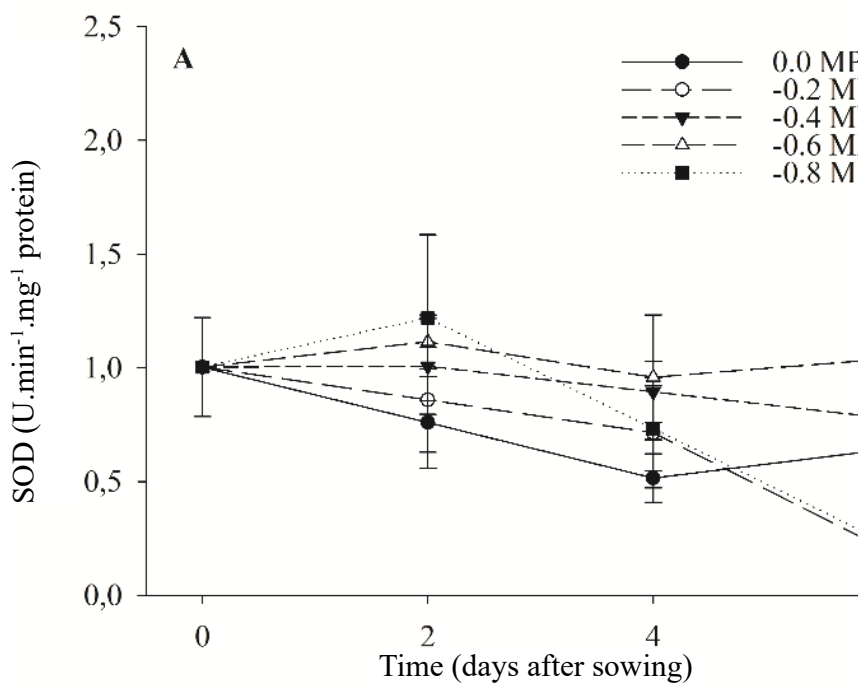

Lot 2

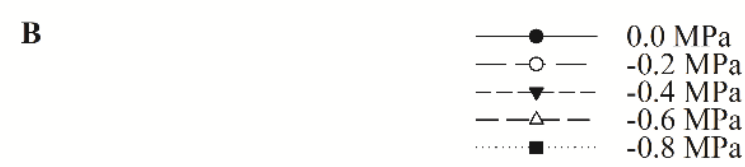

Bars: standard deviation

Figure 3. Activity of the enzyme superoxide dismutase (SOD) determined at $0,2,4$ and 6 days after sowing for seedlings from lots 1 (A) and 2 (B) of sunflower, cultivar Hélio 253, under water restriction in PEG 6000 solutions.

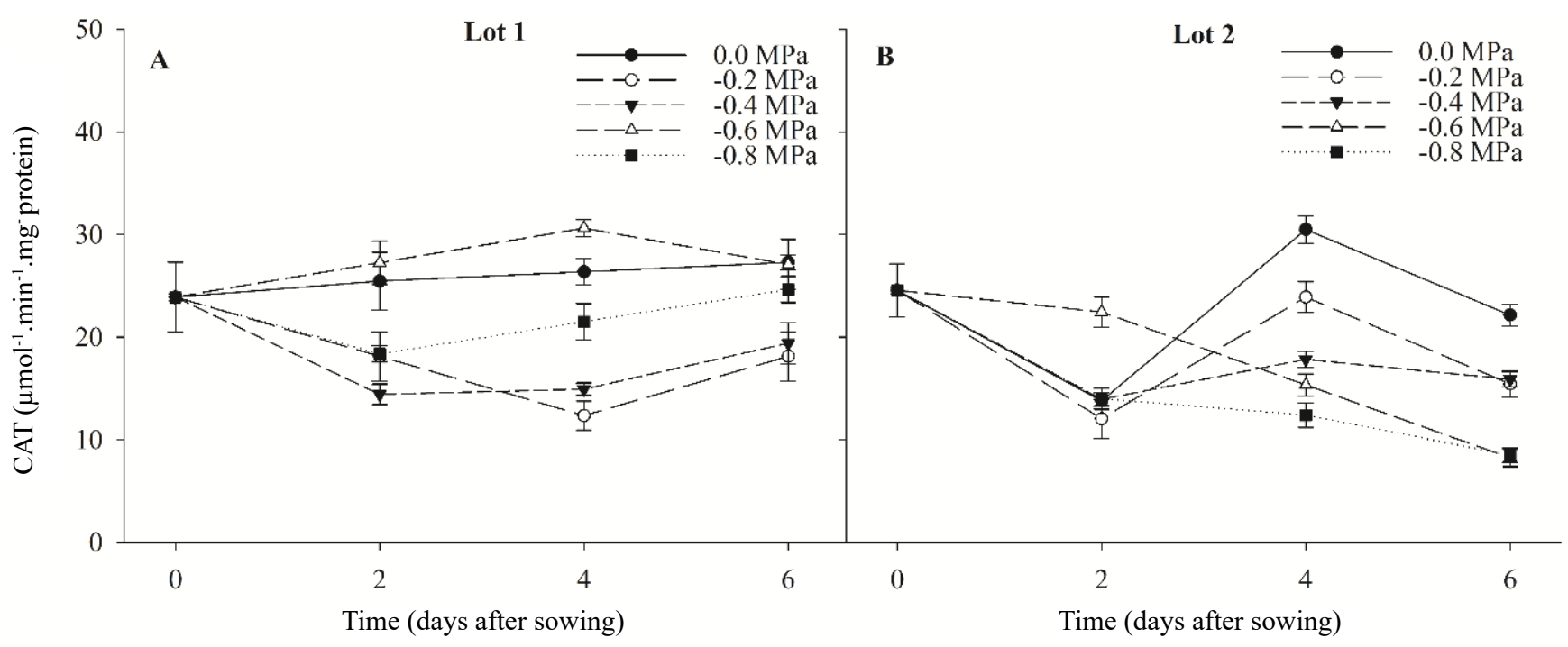

Bars: standard deviation.

Figure 4. Activity of the enzyme catalase (CAT) determined at 0, 2, 4 and 6 days after sowing for seedlings from lots 1 (A) and 2 (B) of sunflower, cultivar Hélio 253, under water restriction in PEG 6000 solutions. 
0 and $-0.2 \mathrm{MPa}$ resulted in higher POX activity, regardless of the exposure time. In lot 1 (higher vigor), this increase was more accentuated from the second day on, with an even more significant increase from the fourth day on (Figure 5A).

In lot 2 (lower vigor), this increase was less accentuated, especially for the potentials of $-0.4,-0.6$ and $-0.8 \mathrm{MPa}$ (Figure 5B). These results may be due to the delay in seedling development and to the sensitivity of the less vigorous lots to stress. However, as CAT activity was greater (Figures $4 \mathrm{~A}$ and $\mathrm{B}$ ) and these enzymes exercise similar functions, such observations may also be associated with equilibrium of activity of these enzymes, especially in relation to lot 2 . Similar to the present study, Manivannan et al. (2014) reported increases in POX activity in roots, stems and leaves of five sunflower cultivars under water stress.

The APX enzyme participates in conversion of $\mathrm{H}_{2} \mathrm{O}_{2}$ into $\mathrm{O}_{2}$ through a series of oxidations in the glutathione/ ascorbate cycle (Caverzan et al., 2012). Similar to POX, APX activity was more accentuated for the higher vigor lot (Figures $6 \mathrm{~A}$ and $\mathrm{B}$ ). These results are in agreement with germination percentage and shoot and root length, which

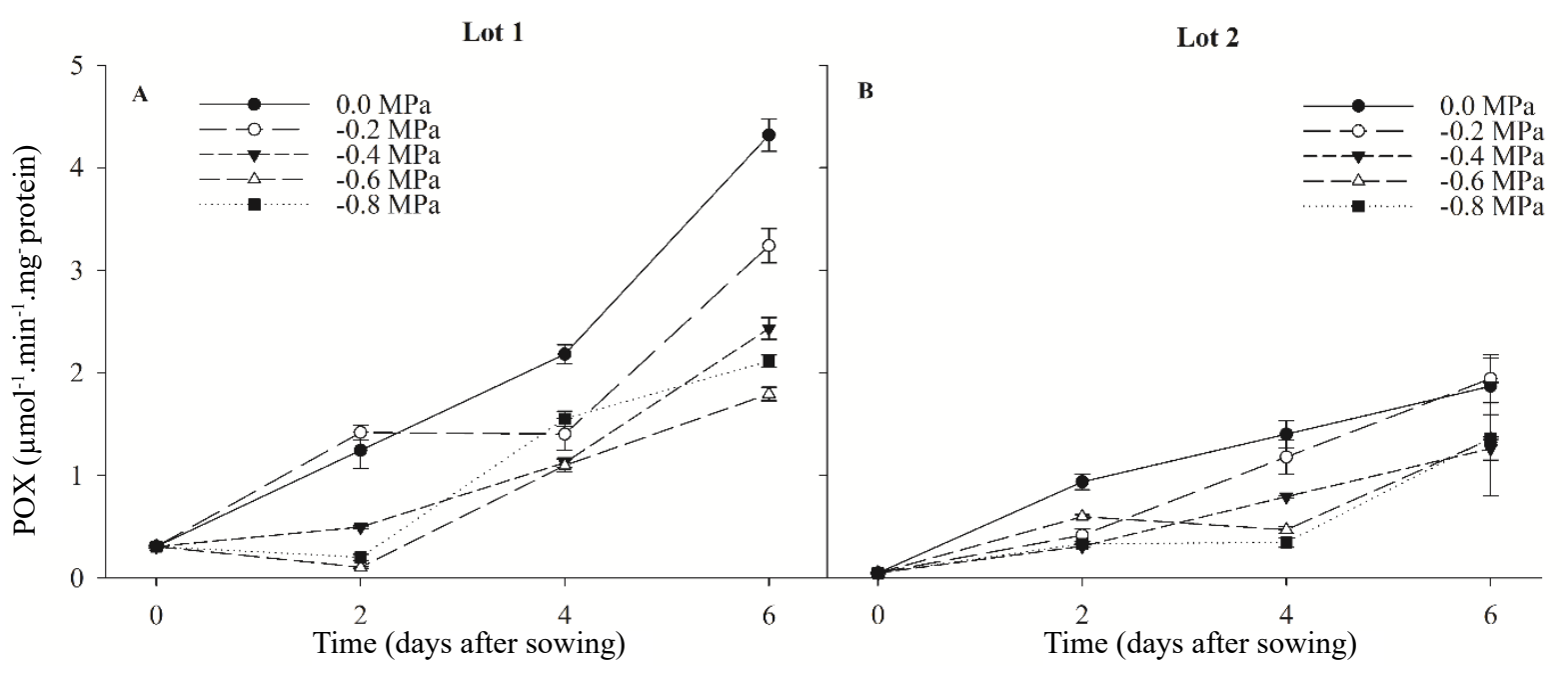

Bars: standard deviation.

Figure 5. Activity of the enzyme peroxidase (POX) determined at 0, 2, 4 and 6 days after sowing for seedlings from lots 1 (A) and 2 (B) of sunflower, cultivar Hélio 253, under water restriction in PEG 6000 solutions.

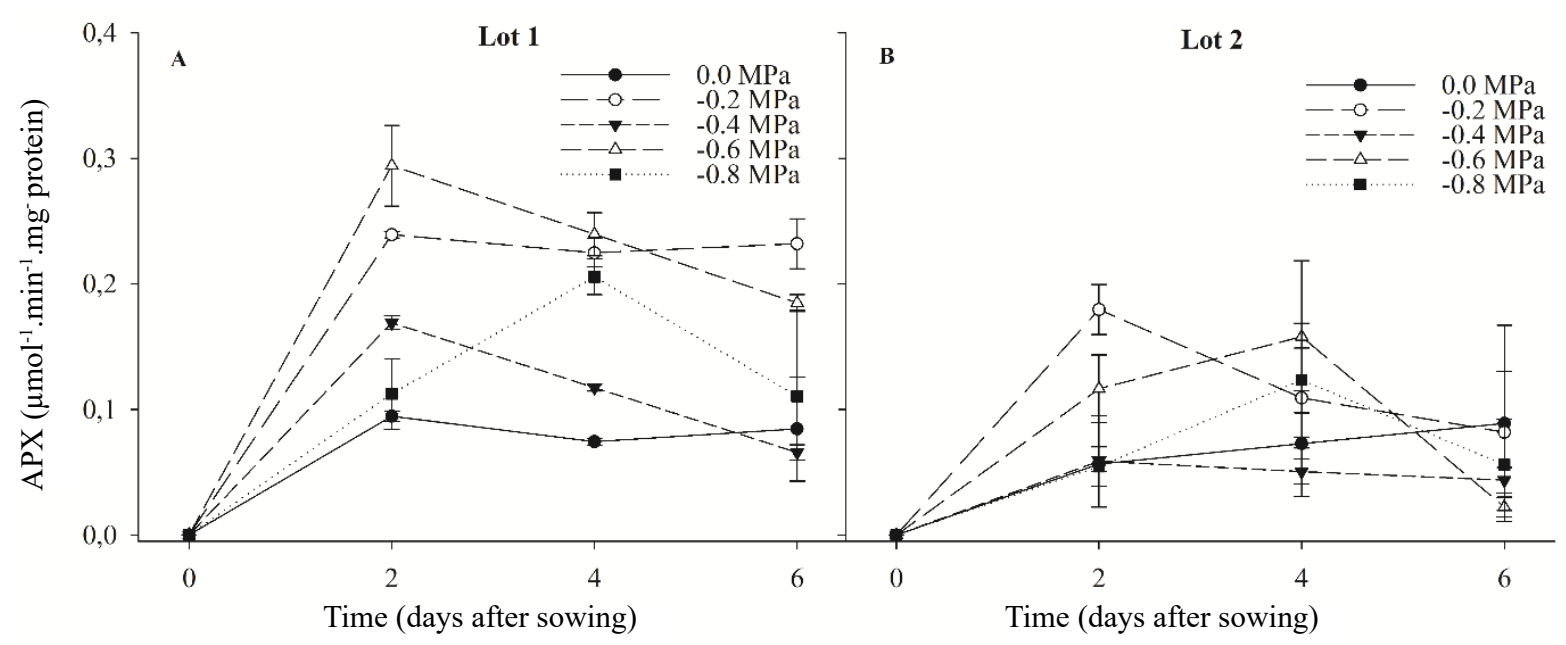

Bars: standard deviation.

Figure 6. Activity of the enzyme ascorbate peroxidase (APX) determined at $0,2,4$ and 6 days after sowing for seedlings from lots 1 (A) and 2 (B) of sunflower, cultivar Hélio 253, under water restriction in PEG 6000 solutions. 
were lower in the lower quality lot when the seeds were placed under water restriction (Figures 1 and 2).

In lot 1, there was an increase in APX activity on the second day in all the treatments, and the greatest activity was found at the potential of $-0.6 \mathrm{MPa}$ and the lowest activity in the control treatment. From the fourth day on, APX activity at the water potential of $-0.8 \mathrm{MPa}$ declined significantly, while in the treatments with a lower level of stress, activity declined especially from the second day on (Figure 6A).

In a way similar to lot 1 , lot 2 (lower vigor) generally had greater APX activity in relation to the control in all the periods evaluated, especially from the second day on (Figure 6B). Chakraborty and Pradhan (2012) found an increase in the activity of this enzyme in wheat seedlings on the third day of germination under water stress. Baloğlu et al. (2012) conducted a study on the effect of water stress in sunflower seedlings and concluded that APX is important for protection of root tissues in this species under more severe stress conditions. Locato et al. (2010) affirm that some enzymes of the peroxidase family are expressed in a constitutive manner. Others may be induced by environmental stresses, such that under more intense stress situations, there is greater activity of the APX enzyme.

It is important to emphasize that the ROSs are predominantly beneficial to plant metabolism, performing diverse functions, from germination to cell signaling (Mittler, 2017). In addition, Manivannan et al. (2014) state that the level of enzyme activity of the antioxidant system depends not only on the species and vigor, but also on the duration and intensity of the stress, which was generally observed in this study. In general, considering the enzymes that act as peroxidases (CAT, POX, and APX), an increase can be seen in the activity with the longer time of exposure to water restriction, especially for the seeds with highest vigor (lot 1).

\section{CONCLUSIONS}

Water restriction led to a decrease in germination and lower growth of seedlings, regardless of the vigor level of the seeds.

Water restriction affects antioxidant enzyme activity in sunflower seeds, especially beginning at two days of exposure to stress.

Lower vigor seeds have lower capacity for activation of antioxidant enzymes, especially the peroxidases.

\section{ACKNOWLEDGMENTS}

Our thanks to the Plant Science Department of the Universidade Federal de Viçosa (UFV). Thanks also to the Conselho Nacional de Desenvolvimento Científico e Tecnológico (CNPq), to the Coordenação de Aperfeiçoamento de Pessoal de Nível Superior (CAPES), finance code 001, and to the Fundação de Amparo à Pesquisa do Estado de Minas Gerais (FAPEMIG) for funding.

\section{REFERENCES}

ALBUQUERQUE, M.C.F.E.; CARVALHO, N.M. Effect of the type of environmental stress on the emergence of sunflower (Helianthus annus L.), soybean (Glycine max (L.) Merrill) and maize (Zea mays L.) seeds with different levels of vigor. Seed Science and Technology. v.31, n.2, p. 465-479, 2003. https://www.cabdirect.org/cabdirect/abstract/20046700035

ANDERSON, M.D.; PRASAD, T.K.; STEWART, C.R. Changes in isozyme profiles of catalase, peroxidase and glutathione reductase during acclimation to chilling in mesocotyls of maize seedlings. Plant Physiology, v.109, n.4, p.1247-1257, 1995. https://doi. org/10.1104/pp.109.4.1247

ÁVILA, M.R.; BRACCINI, A.L.; SCAPIM, C.A. Teste de comprimento de plântulas sob estresse hídrico. Revista Brasileira de Sementes. v.29, n.2, p.117-124, 2007. http://www.scielo.br/pdf/rbs/v29n2/v29n2a16

BACKES, R.L.; SOUZA, A.M.; BALBINOT JUNIOR, A.A.; GALLOTTI, G.J.M.; BAVARESCO, A. Desempenho de cultivares de girassol em duas épocas de plantio de safrinha no planalto norte catarinense. Scientia Agraria, v.9, n.1, p.41-48, 2008. http://www.redalyc. org/articulo.oa?id=99516828007 
BAILLY, C. Active oxygen species and antioxidants in seed biology. Seed Science Research, v.14, n.2, p.93-107, 2004. https://doi. org/10.1079/SSR2004159

BAILLY, C.; EL-MAAROUF-BOUTEAU, H.; CORBINEAU, F. From intracellular signaling networks to cell death: the dual role of reactive oxygen species in seed physiology. Comptes Rendus Biologies, v.331, n.10, p.806-814, 2008. https://doi.org/10.1016/j. crvi.2008.07.022

BALOĞLU, M.C.; KAVAS, M.; AYDIN, G.; ÖKTEM, H.A.; YÜCEL, A.M. Antioxidative and physiological responses of two sunflower (Helianthus annuus) cultivars under PEG-mediated drought stress. Turkish Journal of Botany, v.36, n.6, p.707-714, 2012. http:// journals.tubitak.gov.tr/botany/issues/bot-12-36-6/bot-36-6-11-1111-20.pdf

BARROS, C.S.; ROSSETTO, C.A.V. Condicionamento fisiológico de aquênios de girassol. Ciência Rural, v.39, n.6, p.1667-1675, 2009. http://www.scielo.br/scielo.php?script=sci_arttext\&pid=S0103-84782009000600006\&lng=pt\&tlng=pt

BEAUCHAMP, C.; FRIDOVICH, I. Superoxide dismutase: improved assays and an assay applicable to acrylamide gels. Analytical Biochemistry. v.44, n.1, p.276-287, 1971. https://doi.org/10.1016/0003-2697(71)90370-8

BEWLEY, J.D.; BRADFORD, K.J.; HILLHORST, H.W.M.; NONOGAKI, H. Seeds: physiology of development, germination and dormancy (3. ed.). New York: Springer Science and Business Media, 2013. 407p.

BRADFORD, M.M. A rapid and sensitive method for the quantitation of microgram quantities of protein utilizing the principle of protein-dye binding. Analytical Biochemistry, v.72, n.1-2, p.248-254, 1976. https://doi.org/10.1016/0003-2697(76)90527-3

BRASIL. Ministério da Agricultura, Pecuária e Abastecimento. Regras para análise de sementes. Ministério da Agricultura, Pecuária e Abastecimento. Secretaria de Defesa Agropecuária. Brasília: MAPA/ACS, 2009. 395p. http:// www.agricultura.gov.br/arq_editor/ file/2946_regras_analise_sementes.pdf

CARNEIRO, M.M.L.C.; DEUNER, S.; OLIVEIRA, P.D.; TEIXEIRA, S.B.; SOUSA, C.P.; BACARIN, M.A.; MORAES, D.D. Ação de agentes indutores de estresse na viabilidade e atividade antioxidante em sementes de girassol. Journal of Seed Science, v.33, n.4, p.752761, 2011. https://submission3.scielo.br/index.php/jss/article/view/42891

CAVERZAN, A.; PASSAIA, G.; BARCELLOS ROSA, S.; RIBEIRO, C.W.; LAZZAROTTO, F.; MARGIS-PINHEIRO, M. Plant responses to stresses: role of ascorbate peroxidase in the antioxidant protection. Genetics and Molecular Biology, v.35, n.4, p.1011-1019, 2012. http://dx.doi.org/10.1590/S1415-47572012000600016

CHAKRABORTY, U.; PRADHAN, B. Oxidative stress in five wheat varieties (Triticum aestivum L.) exposed to water stress and study of their antioxidant enzyme defense system, water stress responsive metabolites and $\mathrm{H}_{2} \mathrm{O}_{2}$ accumulation. Brazilian Journal of Plant Physiology, v.24, n.2, p.117-130, 2012. http://dx.doi.org/10.1590/S1677-04202012000200005

CHANCE, B.; MAEHLY, A.C. Assay of catalases and peroxidases. Methods in Enzymology, v.2, p.764-775, 1955. https://doi. org/10.1016/S0076-6879(55)02300-8

CHEN, K.; ARORA, R. Priming memory invokes seed stress-tolerance. Environmental and Experimental Botany, v.94, p.33-45, 2013. https://doi.org/10.1016/j.envexpbot.2012.03.005

CONAB. Companhia Nacional de Abastecimento. Conjuntura mensal da produção de girassol, 2017. 7p.

DEL LONGO, O.T.; GONZÁLEZ, C.A.; PASTORI, G.M.; TRIPPI, V.S. Antioxidant defences under hyperoxygenic and hyperosmotic conditions in leaves of two lines of maize with differential sensitivity to drought. Plant and Cell Physiology, v.34, n.7, p.1023-1028, 1993. https://doi.org/10.1093/oxfordjournals.pcp.a078515

DEL RÍO, L.A.; CORPAS, F.J.; LÓPEZ-HUERTAS, E.; PALMA, J.M. Plant superoxide dismutases: function under abiotic stress conditions. In: Antioxidants and Antioxidant Enzymes in Higher Plants Cham: Springer International Publishing, 2018. p.1-26.

FARJZADEH, E.; VALIZADEH, M.; SHAKIBA, M.; GHAFFARI, M. Study of some biochemical attributes responses to water deficit stress on sunflower lines. Advances in Bioresearch, v.8, n.3, p.85-90, 2017. http://soeagra.com/abr/may_2017/15.pdf

FERNÁNDEZ-OCAÑA, A.; CHAKI, M.; LUQUE, F.; GÓMEZ-RODRÍGUEZ, M.V.; CARRERAS, A.; VALDERRAMA, R.; BEGARA-MORALES, J.C.; HERNANDEZ, L.E.; CORPAS, F.J.; BARROSO, J.B. Functional analysis of superoxide dismutases (SODs) in sunflower under biotic and abiotic stress conditions. Identification of two new genes of mitochondrial Mn-SOD. Journal of Plant Physiology, v.168, n.11, p.1303-1308, 2011. https://doi.org/10.1016/j.jplph.2011.01.020 
FINCH-SAVAGE, W.E.; BASSEL, G.W. Seed vigour and crop establishment: extending performance beyond adaptation. Journal of Experimental Botany, v.67, n.3, p.567-591, 2016. https://doi.org/10.1093/jxb/erv490

GIANNOPOLITIS, C.N.; RIES, S.K. Superoxide dismutases: I. occurrence in higher plants. Plant Physiology, v.59, p.309-314, 1977. https://www.ncbi.nlm.nih.gov/pmc/articles/PMC542387/pdf/plntphys00136-0196.pdf

GONZÁLEZ-BELO, R.; TOGNETTI, J.; BENECH-ARNOLD, R.; IZQUIERDO, N.G. Germination responses to temperature and water potential as affected by seed oil composition in sunflower. Industrial Crops and Products, v.62, p.537-544, 2014. https://doi. org/10.1016/j.indcrop.2014.09.029

GROß, F.; DURNER, J.; GAUPELS, F. Nitric oxide, antioxidants and prooxidants in plant defence responses. Frontiers in Plant Science, v.4, n.419, p.1-15, 2013. https://doi.org/10.3389/fpls.2013.00419

HAVIR, E.A.; MCHALE, N.A. Biochemical and developmental characterization of multiple forms of catalase in tobacco leaves. Plant Physiology, v.84, n.2, p.450-455, 1987. https://doi.org/10.1104/pp.84.2.450

JALEEL, C.A.; MANIVANNAN, P.; SANKAR, B.; KISHOREKUMAR, A.; GOPI, R.; SOMASUNDARAM, R.; PANNEERSELVAM, R. Water deficit stress mitigation by calcium chloride in Catharanthus roseus: effects on oxidative stress, proline metabolism and indole alkaloid accumulation. Colloids and Surfaces B: Biointerfaces, v.60, n.1, p.110-116, 2007. https://doi.org/10.1016/j.colsurfb.2007.06.006

JISHA, K.C.; VIJAYAKUMARI, K.; PUTHUR, J.T. Seed priming for abiotic stress tolerance: an overview. Acta Physiologiae Plantarum, v.35, n.5, p.1381-1396, 2013. https://link.springer.com/article/10.1007/s11738-012-1186-5

KAPOOR, D.; SHARMA, R.; HANDA, N.; KAUR, H.; RATTAN, A.; YADAV, P.; GAUTAM, V.; KAUR, R.; BHARDWAJ, R. Redox homeostasis in plants under abiotic stress: role of electron carriers, energy metabolism mediators and proteinaceous thiols. Frontiers in Environmental Science, v.3, n.13, p.1-12, 2015. https://doi.org/10.3389/fenvs.2015.00013

KIBINZA, S.; BAZIN, J.; BAILLY, C.; FARRANT, J.M.; CORBINEAU, F.; EL-MAAROUF-BOUTEAU, H. Catalase is a key enzyme in seed recovery from ageing during priming. Plant Science, v.181, n.3, p.309-315, 2011. https://www.ncbi.nlm.nih.gov/pubmed/21763542

LEWANDROWSKI, W.; ERICKSON, T.E.; DIXON, K.W.; STEVENS, J.C. Increasing the germination envelope under water stress improves seedling emergence in two dominant grass species across different pulse rainfall events. Journal of Applied Ecology, v.54, n.3, p.997-1007, 2017. https://doi.org/10.1111/1365-2664.12816

LOCATO, V.; PINTO, M.C.; PARADISO, A.; GARA, L. Reactive oxygen species and ascorbate glutathione interplay in signaling and stress responses. In: GUPTA, S.D. Reactive oxygen species and antioxidants in higher plants. Enfield: Science Publishers, 2010. p.45-64.

LUAN, Z.; XIAO, M.; ZHOU, D.; ZHANG, H.; TIAN, Y.; WU, Y.; GUAN, B.; SONG, Y. Effects of salinity, temperature and polyethylene glycol on the seed germination of sunflower (Helianthus annuus L.). The Scientific World Journal, v.2014, n.2014, p.1-9, 2014. http://dx.doi.org/10.1155/2014/170418

MAGUIRE, J.D. Speed of germination - aid selection and evaluation for seedling emergence and vigor. Crop Science, v.2, n.2, p.176177, 1962. http://dx.doi.org/10.2135/cropsci1962.0011183X000200020033x

MANIVANNAN, P.; RABERT, G. A.; RAJASEKAR, M.; SOMASUNDARAM, R. Drought stress induced modification on growth and pigments composition in different genotypes of Helianthus annuus L. Current Botany, v.5, p.7-13, 2015. http://updatepublishing. com/journal/index.php/cb/article/view/2937

MANIVANNAN, P.; RAJASEKAR, G.A.M.; SOMASUNDARAM, R. Analysis of antioxidant enzyme activity in various genotypes of Helianthus annuus L. (sunflower) under varied irrigation regimes. Food Biology, v.3, p.1-10, 2014. http://updatepublishing.com/ journal/index.php/fb/article/view/2950

MARCOS-FILHO, J. Fisiologia de sementes de plantas cultivadas. Londrina: ABRATES, 2015. 659p.

MITTLER, R. Oxidative stress, antioxidants and stress tolerance. Trends in Plant Science, v.7, n.9, p.405-410, 2002. https://doi. org/10.1016/S1360-1385(02)02312-9

MITTLER, R. ROS are good. Trends in Plant Science, v.22, n.1, p.11-19, 2017. https://doi.org/10.1016/j.tplants.2016.08.002

MOHARRAMNEJAD, S.; SOFALIAN, O.; VALIZADEH, M.; ASGARI, A.; SHIRI, M. Proline, glycine betaine, total phenolics and pigment contents in response to osmotic stress in maize seedlings. Journal of BioScience and Biotechnology, v.4, n.3, p.313-319, 2015. https://pdfs.semanticscholar.org/700c/b78945567cce729649c3ba953c97fd6d00c8.pdf 
MOURADI, M.; BOUIZGAREN, A.; FARISSI, M.; MAKOUDI, B.; KABBADJ, A.; VERY, A.; SENTENAC, H.; QADDOURY, A.; GHOULAM, C. Osmopriming improves seeds germination, growth, antioxidant responses and membrane stability during early stage of $M o r o c c a n$ alfalfa populations under water deficit. Chilean Journal of Agricultural Research, v.76, n.3, p.265-272, 2016. http://dx.doi. org/10.4067/S0718-58392016000300002

NADERI, R.; VALIZADEH, M.; TOORCHI, M.; SHAKIBA, M.R. Antioxidant enzyme changes in response to osmotic stress in wheat (Triticum aestivum L.) seedling. Acta Biologica Szegediensis, v.58, n.2, p.95-101, 2014. http://abs.bibl.u-szeged.hu/index.php/abs/ article/view/2823

NAKAGAWA, J.; KRZYZANOWSKI, F.C.; VIEIRA, R.D.; FRANÇA-NETO, J.B. Testes de vigor baseados no desempenho das plântulas. In: Vigor de sementes: conceitos e testes. Londrina: ABRATES, 1999. p.9-13.

NAKANO, Y.; ASADA, K. Hydrogen peroxide is scavenged by ascorbate-specific peroxidase in spinach chloroplasts. Plant and Cell Physiology, v.22, n.5, p.867-880, 1981. https://doi.org/10.1093/oxfordjournals.pcp.a076232

NGUYEN, K.H.; MOSTOFA, M.G.; WATANABE, Y.; TRAN, C.D.; RAHMAN, M.M.; TRAN, L - S.P. Overexpression of GmNAC085 enhances drought tolerance in Arabidopsis by regulating glutathione biosynthesis, redox balance and glutathione-dependent detoxification of reactive oxygen species and methylglyoxal. Environmental and Experimental Botany, v.161, p.242-254, 2019. https://doi. org/10.1016/j.envexpbot.2018.12.021

PEIXOTO, P.H.P.; CAMBRAIA, J.; SANT'ANNA, R.; MOSQUIM, P.R.; MOREIRA, M.A. Aluminum effects on lipid peroxidation and on the activities of enzymes of oxidative metabolism in sorghum. Revista Brasileira de Fisiologia Vegetal, v.11, n.3, p.137-143, 1999.

SAVVIDES, A.; ALI, S.; TESTER, M.; FOTOPOULOS, V. Chemical priming of plants against multiple abiotic stresses: mission possible? Trends in Plant Science, v.21, n.4, p.329-340, 2016. https://doi.org/10.1016/j.tplants.2015.11.003

SINGH, N.B.; SINGH, D.; SINGH, A. Biological seed priming mitigates the effects of water stress in sunflower seedlings. Physiology and Molecular Biology of Plants, v.21, n.2, p.207-214, 2015. https://doi.org/10.1007/s12298-015-0291-5

VILLELA, F.A.; DONI FILHO, L.; SEQUEIRA, E.L. Tabela de potencial osmótico em função da concentração de polietileno glicol 6.000 e da temperatura. Pesquisa Agropecuária Brasileira, v.26, n.11-12, p.1957-1968, 1991.

WANG, W.; XIA, M.X.; CHEN, J.; YUAN, R.; DENG, F.N.; SHEN, F.F. Gene expression characteristics and regulation mechanisms of superoxide dismutase and its physiological roles in plants under stress. Biochemistry (Moscow), v.81, n.5, p.465-480, 2016. https:// doi.org/10.1134/S0006297916050047

WILLEKENS, H.; INZÉ, D.; VAN MONTAGU, M.; VAN CAMP, W. Catalases in plants. Molecular Breeding, v.1, p.207-228, 1995. https:// link.springer.com/content/pdf/10.1007/BF02277422.pdf

XIN, X.; TIAN, Q.; YIN, G.; CHEN, X.; ZHANG, J.; NG, S.; LU, X. Reduced mitochondrial and ascorbate-glutathione activity after artificial ageing in soybean seed. Journal of Plant Physiology, v.171, n.2, p.140-147, 2014. https://doi.org/10.1016/j.jplph.2013.09.016

YIN, X.; HE, D.; GUPTA, R.; YANG, P. Physiological and proteomic analyses on artificially aged Brassica napus seed. Frontiers in Plant Science, v.6, n.112, p.1-11, 2015. https://doi.org/10.3389/fpls.2015.00112 use, distribution, and reproduction in any medium, provided the original work is properly cited. 